place of agriculture in the life of the nation, with special reference to the soil, its cultivation and improvement, grassland and arable crops, livestock husbandry, the processing and distribution of farm products, and the social and economic conditions of rural life. The school should appeal particularly to all teachers of biology, and social workers and others will be able to extend their knowledge of and sympathy with the work, outlook and social conditions of the rural community.

At the evening sessions, lectures will be given by visiting speakers, each expert in his special field. Among those who have already accepted invitations to speak are the Rt. Hon. R. K. Law, Prof. A. W. Ling, Prof. 'T. Wallace, Prof. D. B. Johnstone-Wallace, Mr. L. J. F. Brimble, Mr. J. H. Anderson, Mr. E. Ford, Mr. G. F. Kingston, Mr. K. C. Vear and Dr. D. A. MacPherson. The resident staff will consist of Mr. A. Roebuck, Miss H. R. Chapman, Mr. W. L. Sumner, Mr. E. Lucas, Mr. L. E. Morris, Mr. R. Weatherall and Dr. M. B. Gibbons. The fee for the School is $£ 14$ 14s. (including £l 1s. enrolment fee-not returnable). This covers board and tuition. Further information can be obtained from the Secretary, British Social Hygiene Council, Dept. S.J.1, Tavistock House North, Tavistock Square, London, W.C.1.

\section{University of Leeds: Appointments}

THE following appointments in the University of Leeds have been announced: Dr. J. W. Baker, formerly senior lecturer and honorary reader in organic chemistry, to the newly established readership in the mechanism of organic reactions; Dr. C. S. Whewell, lecturer in textile chemistry, to be honorary reader in textile finishing and lecturer in textile chemistry.

\section{University of Sheffield}

THE following appointments in the University of Sheffield have been announced : O. I. Butler, senior lecturer in charge of the Department of Electrical Engineering; H. J. Cowan, lecturer in civil engineering ; G. Wiseman, assistant lecturer in physiology ; A. G. Macgregor, research assistant in the Department of Pharmacology and Therapeutics.

Prof. Douglas Knoop, who is retiring from the chair of economics at the end of the present session, has made a gift of money to the University to endow an economics prize, to be associated with his name, to be awarded to the student whose work in economics in the final examination for the Special Degree of B.A. has shown most distinction and promise.

\section{Colonial Service : Appointments}

THE following appointments in the Colonial Service have been announced: D. D. Campbell, agricultural officer, Uganda; H. Irving, agricultural chemist, Nigeria ; D. C. Todd, agricultural officer, Uganda; G. H. Pinfield, inspector of mines, Tanganyika; L. F. Edgerley, assistant conservator of forests, Mauritius; B. R. Fuller, assistant conservator of forests, Nyasaland; S. T. Hoyle, senior agricultural officer, Lilongwe Experimental Station, Nyasaland; J. Sinclair, curator of the Herbarium, Singapore; S. Gillet (senior coffee officer, Kenya), director of agriculture, Kenya ; J. T. Moon (agricultural officer, Kenya), senior agricultural officer, Kenya; C. C. Parisionos (agricultural officer, Northern Rhodesia), agricultural officer, Cyprus ; A. Pickles (entomologist, Trinidad), entomologist, Nigeria; F. W. Thomas (agricultural officer, Tanganyika), senior agricultural officer, Tanganyika; J. P. Edwards (conservator of forests, Malaya), deputy director of forestry, Malaya; R. O. Roberts (chemist and petrologist, Uganda), mineralogist, Nigeria ; D. F. Macpherson (senior veterinary officer, Kenya), chief veterinary officer, Nyasaland; F. L. Vanderplank (research officer, Tanganyika), entomologist, West African Institute for Trypanosomiasis.

\section{The Night Sky in April}

New moon occurs on April 9d. 13h. 16m., U.T., and full moon on April 23d. 13h. 28m. The following conjunctions with the moon take place: April 7d. 18h., Mercury $2^{\circ}$ N.; April 13d. 08h., Venus $1^{\circ}$ N.; April 18d. 02h., Saturn $4^{\circ}$ S. ; April 18d. 10h., Mars $3^{\circ}$ S. ; April 27d. 18h., Jupiter $4^{\circ}$ N. ; Mercury, in superior conjunction with the sun on April 29, is too close to the sun during the month for favourable observation. Venus is an evening star, setting at $22 \mathrm{~h} .56 \mathrm{~m}$. and $23 \mathrm{~h} .45 \mathrm{~m}$. on April 1 and 30 respectively, and shines with stellar magnitude -4 approximately during the month, about one half of the illuminated portion of the disk being visible. The planet attains its greatest easterly elongation on April 15. Mars, in the constellation of Leo, can be seen throughout the greater portion of the night, setting at $4 \mathrm{~h}$. $25 \mathrm{~m} ., 3 \mathrm{~h} .23 \mathrm{~m}$., and $2 \mathrm{~h} .4 \mathrm{~lm}$., at the beginning, middle and end of the month, respectively. Jupiter, in the constellation of Sagittarius, is not visible until the early morning hours, the times of rising being $1 \mathrm{~h} .25 \mathrm{~m}$. on April 1 and $23 \mathrm{~h}$. $30 \mathrm{~m}$. on April 30. The planet is stationary on April 15. Saturn, in the constellation of Cancer, is visible during most of the night, setting a little before Mars, and is stationary on April 17. Occultations of stars brighter than magnitude 6 are as follows: April 13d. 20h. 3lm., $k$ Taur. $(D)$; April 26d. 00h. I6m. 19 Scor. $(R) ; D$ and $R$ refer to disappearance and reappearance, respectively, and the latitude of Greenwich is assumed. There will be a partial eclipse of the moon on April 23, invisible at Greenwich, but visible over a large portion of the southern hemisphere and also over the extreme western and north. western portion of North America. The Lyrid meteors can be seen during April 18-24, but moonlight will partly interfere with the observations of this shower.

\section{Announcements}

THE governing body of the Imperial College of Science and Technology has appointed Air Chief Marshal Sir Roderic Hill to be rector of the College as from October 1, in succession to Sir Richard Southwell, who has held that office since 1942.

Dr. J. Cymerman, lecturer in organic chemistry in Charing Cross Hospital Medical School (University of London), has been appointed lecturer in organic chemistry in the University of Sydney.

Tre following have been elected officers of the Royal Photographic Society: President, Percy W. Harris; Vice-Presidents, L. V. Chilton, I. D. Wratten ; Treasurer, H. Abbott; Ordinary Members of Council, Gilbert Adams, J. Allan Cash, K. H. Gaseltine, R. N. Haile, Dr. P. Hansell, T. Midgley Illingworth, Dr. S. D. Jouhar, Mrs. Rosalind Main. got, R. H. Mason, H. S. Newcombe, Alec Pearlman, Anthony Peacock, Oliver G. Pike, B. Sinkinson, A. L. M. Sowerby. 